\title{
Can 2-Aticyto Complex be an Effective Agent for Recovery of The Symptoms and Enhancing Laboratory Parameters in COVID-19 Patients?
}

\author{
Ferhan Kerget, Buğra Kerget, Alperen Aksakal, and Abdullah Osman Koçak
}

\section{ABSTRACT}

Background: SARS-CoV-2 (Covid-19) pandemic which was firstly identified in Wuhan/China in December 2019.There still exists no precise treatment for this pandemic yet despite many agents are tried in prophylaxis and treatment for Covid-19. In this study, we aimed to investigate the efficacy of 2 -aticyto complex in clinical course in these patients.

Materials and Methods: 150 patients who applied to the Infection Diseases Polyclinics between dates September 2020-November 2020 having diagnosed with Covid-19 were included in our study. The patients were randomized into 2 groups (75 in each group) of which the first group only had the treatment of National Guideline and the second group had Viruthol ${ }^{\circledR}$ including 2-aticyto complex (at the dose of $27000 \mathrm{mcg} / \mathrm{day}$ ) in addition to the treatment of the National Guideline. The laboratory parameters, clinical outcomes and the first day on which PCR result turned into negative of the patients were compared.

Results: In Viruthol ${ }^{\circledR}$ group, LDH, CRP, D-Dimer and ferritin levels were significantly decreased compared to the control group, while lymphocyte levels were higher. $(p=0.02, p=0.001, p=0.01, p=0.02, p=0,001$ respectively). In addition to that, clinical symptoms such as fever, headache, weakness, loss of taste and smell and muscle-joint pain recovered more rapidly in contrast with the control group $(p=0.001, p=0.05, p=0.001, p=0.001$, $p=0.001$, respectively). PCR results of the Viruthol ${ }^{\circledR}$ group turned negative in a statistically significant shorter period of time with respect to the control group $(\mathbf{p}=\mathbf{0 . 0 0 1})$.

Conclusion: Viruthol ${ }^{\circledR}$ containing 2-aticyto complex may be an agent that can be used both symptomatic treatment and improving the clinical situation and recovery of the patients followed up for Covid-19.

Keywords: COVID-19, 2-aticyto complex, traditional medicine, treatment.
Submitted : February 27, 2021

Published : March 20, 2021

ISSN: $2593-8339$

DOI: $10.24018 /$ ejmed.2021.3.2.745

Ferhan Kerget *

Depertmant of Infection Diseases and Clinical Microbiology, Health Sciences University, Erzurum Regional Education and Research Hospital, Erzurum, Turkey.

(e-mail: drferhan68@hotmail.com)

Buğra Kerget

Depertmant of Pulmonology, Ataturk University, Erzurum, Turkey.

Alperen Aksakal

Depertmant of Pulmonology, Health

Sciences University, Erzurum Regional Education and Research Hospital, Erzurum, Turkey.

Abdullah Osman Koçak

Depertmant of Emergency Medicine, Ataturk University, Erzurum, Turkey.

*Corresponding Author

\section{INTRODUCTION}

COVID-19 disease has started in December 2019 in Wuhan-China and spread all around the world in a short manner of time resulting in more than 60 million people and this number is still continuing to increase day by day [1]. In most of the cases, disease progresses asymptomatically, but on the other hand loss of smell and taste, weakness, pain in throat and joints are the other symptoms that associate the disease. In the worst case especially in elderly people and patients with hypertension, diabetes, HIV, and in diseases that suppress immune system such as long-term immunosuppressant therapy and pregnancy disease may progress in harder conditions [2].

In the prophylaxis and treatment of COVID-19, different treatment perspectives including hydroxychloroquine, favipiravir and remdesivir administration was experienced up to date and some resulted in the idea that they may be effective in some cases [3]-[5]. Ascorbic acid (Vitamin C) is an important antioxidant agent that has been clinically experienced on a set of diseases and intensive care patients from the perspective of antioxidant properties [6]. It attenuates the stress response in sepsis patients and exerts antiviral activity through supporting lymphocyte activity, enhancing interferon- $\alpha$ production, modulating cytokines, decreasing inflammation, improving endothelium dysfunction, and restoring mitochondrial function [7].

Quercetin (3,3',4'5,7-pentahydroxyflavone) is a naturally occurring flavonoid that is commonly found in various vegetables, leaves, seeds, and grains [8]. In many studies it was proposed that quercetin support may improve antioxidant [9], anti-inflammatory, antiviral [10] and immunoprotective [11] effects. In addition to that depending 
on the promising antiviral effects of quercetin on inhibiting polymerases [12], proteases [13], reverse transcriptase [14], suppressing DNA gyrase and binding viral capsid proteins [15], [16] its efficacy was investigated in various viral infection types and models. The antiviral and antibacterial efficacy of another flavonoid which is carvacrol, has been investigated and proven in a set of other studies. Especially in studies on the human respiratory syncytial virus, it was proven that carvacrol was effective on implantation and replication of the virus to the cell [17].

In this study, we aimed to investigate the efficacy of Viruthol ${ }^{\circledR}$ containing 2-aticyto complex (composed of a special mixture of quercetin, ascorbic acid and carvacrol), on the outcomes of the COVID-19 patients such as clinical, laboratory and PCR negativity.

\section{MATERIALS AND METHODS}

\section{A. Study Design}

In this single center, prospective and randomized controlled clinical study, only the patients from healthcare services were accepted, who applied to infection polyclinic in our hospital with COVID-19 symptoms between September-November 2020. Informed written consent was obtained from all patients included in the study and the study was designed and conducted in accordance with the ethical guidelines set in the Declaration of Helsinki, and the study protocol was approved by the local ethics committee. (B.30.2.ATA.0.01.00/129).

\section{B. Study Population}

150 patients were included in this study among the patients who applied to infection clinics of our hospital for COVID-19 treatment. The patients were carefully experienced for medical control after maximum 24 hours of their PCR positive test results. All patients were also investigated by high resolution Computerized Tomography (CT) at the time of acceptance. The hematological parameters, biochemical parameters including liver and kidney functions, coagulation parameters, ferritin, D-Dimer, troponin-1, procalcitonin and CRP levels were quantified and all of them were repeated after $5^{\text {th }}$ day visit. According to the treatment protocols of the Turkish Ministry of Health, on the $7^{\text {th }}$ day after the first PCR positive result, nasopharyngeal real-time PCR tests were repeated. For the healthcare service patients, they were officially allowed to start working after two negative tests with 24 hours interval; however, in our study for positive cases existing procedure was repeated with 24 hours interval. The day was recorded in which both of the tests were negative. The patients were randomly assigned to two groups (75 patients per group) by an independent physician by using Microsoft $\AA$ Excel Data Randomizer Function.

In our study, patients with existing comorbidity, $\mathrm{PaO}_{2} / \mathrm{FiO}_{2}$ levels equal to or lower than 300 in the arterial blood and an existing allergy history to Helichrysum sp., Hibiscus sabdariffa, Thymbra spicata L.ve Rosa canina L. that exist in the Viruthol ${ }^{\circledR}$ product.

\section{Definitions and Treatment}

Fever was defined as the temperature measured axillary with the value more than $37.3{ }^{\circ} \mathrm{C}$. The diagnosis of acute respiratory failure and grading was done according to the Berlin 2015 diagnosis criteria. Patients were evaluated for the possibility of newly developed cardiac pathologies with echocardiography in case of higher levels of cardiac specific troponin levels. Coagulopathy was defined as prothrombin times with 3 seconds more than normal value and partial thromboplastin levels with 5 seconds more than normal value. Treatment based on the weight of the patients in control group was done according to the elderly diagnosis and treatment guideline of Turkish Republic Ministry of Health Directives for COVID-19. Patients in the treatment group received Viruthol ${ }^{\circledR} 27000 \mathrm{mcg} /$ day in addition to the fore mentioned official treatment perspective of the Ministry of Health. Patients were followed for the perspective of MAS in case of existence of resistant fever, high levels of constantly increasing CRP and ferritin values, D-dimer cytopenia as lymphopenia and thrombocytopenia, abnormalities in liver function test, hypofibrinogenemia or elevation of triglyceride levels.

\section{2-aticyto complex}

2-aticyto complex (purified flavonoid and polyphenol fractions); is a special compound that contains "the certain extent of flavonoid and polyphenol fractions that are produced by purification of Helichrysum sp., Hibiscus sabdariffa, Thymbra spicata L. and Rosa canina L. plants by nanotechnological methods" and also "sodium alginate which is a natural polysaccharide product obtained from the cell wall of brown seaweed grown in cold water regions".

Helichrysum sp, has been used in traditional medicine for its cholinergic, diuretic and expectorant effects in addition to anti-inflammatory and anticancer properties. In a study in which Helichrysum sp. has been used, its content was quantified as neryl acetate $(31 \%), \gamma$-curcumene $(10.7 \%)$, neryl propanoate $(5.1 \%)$, nonyl acetate $(10.5 \%)$, carvacrol (9.8\%), nonyl propanoate $(6.8 \%)$; and ar-curcumene $(6.4 \%)$. [18]. In addition to that in another study, content of Helichrysum sp. oil obtained by hydro-distillation was investigated by gas chromatography (GC) and mas chromatography/mass spectroscopy (GC/MS) method. In total 24 ingredients were characterized in the oil and characteristic volatile components were listed as linalool (1.7\%), anethol (3.2\%), carvacrol (3.6\%) and $\alpha$-muurolol $(1.3 \%)$. The oil also contained significant amounts of aliphatic acids $(34.6 \%)$, their esters $(28.5 \%)$ and other aromatic components $(10.2 \%)$ with respect to the other Helichrysum species [19].

The calix of Hibiscus Sabdariffa L. has been used traditionally as food and herbs depending on its high flavonoid content, specifically high amounts of quercetin and anthocyanin. It was also known that its antibacterial activity was beneficial for human health even at lower concentrations [20].

Thymbra spicata L. is a commonly used herb in drug and food industry depending on strong antifungal, antibacterial and antimicrobial effects of phenolic compounds as carvacrol and thymol [21]. The significant antiviral effect of Thymbra spicata L. against HSV-2 (Herpes Simplex Virus 
type 2) was previously proven in another study [22].

The ascorbic acid content of Rosa canina $\mathrm{L}$. is much more than citrus [23], [24] and contains higher amounts of ascorbic acid with respect to other vegetables and fruits [25]. Similarly, high amounts of phenolic compounds exhibit antioxidant, antimutagenic and anticarcinogenic effects. As well known, phenolic compounds are potential antioxidant molecules that may enhance and benefit human health [26], [27].

Alginates are polyuronic saccharides thar are isolated from cell walls of brown seaweed (Phaeophyceae) and produced as an extracellular matrix by certain soil bacteria (Azotobacter vinelandii and Pseudomonas aeruginosa). It is a low cost, biocompatible and biodegradable polymer which can be decomposed to $\beta$-D-mannuronic acid and $\alpha$-Lglucuronic acid [28]. Alginic acid, sodium and potassium alginate are focus of interest mucoadhesive biomaterials depending on perfect cytocompatibility, biocompatibility, biodegradation, dol-gel transition properties and up-on demand chemical modification characteristics [29]. Another interesting property of alginate is the mucoadhesive property of dry systems, which improves the duration time and enhances release characteristics on intestines, lungs, nose and eye [30]. They have protective properties on the mucous membranes in the upper parts of the gastrointestinal tract with non-toxic characteristics [28].

\section{STATISTICAL ANALYSIS}

The collected data were analyzed using IBM SPSS Statistics for Windows version 20.0 (IBM Corp., Armonk, NY). Pearson's chi-square test and Mann-Whitney U test were used for intergroup comparisons of parametric data and nonnormally distributed numerical data, respectively.
Independent-samples $\mathrm{t}$ test was used to compare demographic data and laboratory parameters between the groups. Wilcoxon analysis was used for intragroup comparisons of laboratory values during follow-up. A pvalue less than 0.05 was considered statistically significant.

\section{RESULTS}

The mean age value of the participants who were included in this study was $33.4 \pm 13.2$. More specifically, mean age was $30.2 \pm 14.6$ for Viruthol ${ }^{\circledR}$ group and $29.8 \pm 15.7$ for control group. In Viruthol ${ }^{\circledR}$ group, gender distribution was $40(53.3 \%)$ males and $35(46.7 \%)$ females, whereas it was $43(57.3 \%)$ males and $32(42.7 \%)$ females in control group. There was no statistically significant difference between age and gender distribution of the patients in this study.

The results of the laboratory tests for the patients were expressed on the first day of hospitalization and on the $5^{\text {th }}$ day in Table 1. A statistically significant decrease was observed in the parameters of LDH, CRP, D-Dimer and ferritin in the Viruthol ${ }^{\circledR}$ group compared to the control group, while the lymphocyte level was higher $(\mathrm{p}=0.001$, $\mathrm{p}=0.02, \mathrm{p}=0.001, \mathrm{p}=0.01, \mathrm{p}=0.02, \mathrm{p}=0,001$ respectively).

In Table 2 and Fig. 1, the observed symptoms at the first time of hospitalization and improvement of the symptoms were given. Statistically significant difference was observed for recovery of fever, headache, weakness, loss of taste and smell, muscle, and joint pain complaints in Viruthol ${ }^{\circledR}$ group with respect to control group $(\mathrm{p}=0.001, \mathrm{p}=0.05, \mathrm{p}=0.001$, $\mathrm{p}=0.001, \mathrm{p}=0.001$, respectively). The evaluation of the PCR positive time parameters also resulted in a significant difference for the Viruthol ${ }^{\circledR}$ group, with shorter duration time for a PCR negativity with respect to control group $(\mathrm{p}=0.001)$.

TABLE 1: COMPARISON OF LABORATORY PARAMETERS OF PATIENTS USING VIRUTHOL $®$ SYRUP AND PATIENTS NONUSING VIRUTHOL $®$ SYRUP FOLLOWED UP DUE TO COVID-19 AT HOSPITAL ADMISSION FIRST DAY AND 5TH DAY OF TREATMENT

\begin{tabular}{|c|c|c|c|c|c|}
\hline & $\begin{array}{l}\text { Admission (n:75) } \\
\text { (Viruthol group) }\end{array}$ & $\begin{array}{c}\text { Day } 5 \text { of } \\
\text { treatment (n:75) } \\
\text { (Viruthol group) }\end{array}$ & $\begin{array}{c}\text { Admission } \\
\text { (n:75) } \\
\text { (Control group) }\end{array}$ & $\begin{array}{c}\text { Day } 5 \text { of } \\
\text { treatment (n:75) } \\
\text { (Control group) }\end{array}$ & $\mathrm{P}$ \\
\hline WBC $(/ \mu \mathrm{L})$ & $9053,7 \pm 2274,7$ & $8955 \pm 1486,3$ & $8463,1 \pm 2254,2$ & $8915,5 \pm 1196,7$ & $0.17 / 0.34$ \\
\hline Lymphocytes $(/ \mu \mathrm{L})$ & $815,1 \pm 324,8$ & $1238,8 \pm 210,2$ & $785,8 \pm 279,6$ & $938,2 \pm 147,4$ & $0.14 / \mathbf{0 . 0 0 1}$ \\
\hline Neutrophils $(/ \mu \mathrm{L})$ & $7604,1 \pm 3321,6$ & $7241,1 \pm 1510,8$ & $7416,3 \pm 2896,9$ & $7196,6 \pm 1704,2$ & $0.45 / 0.55$ \\
\hline NLR & $2,3 \pm 3,1$ & $2,1 \pm 1,6$ & $2,8 \pm 2,6$ & $2,4 \pm 2$ & $0.4 / 0.6$ \\
\hline $\operatorname{AST}(\mathrm{U} / \mathrm{L})$ & $52,1 \pm 19,7$ & $33,5 \pm 26,4$ & $48,4 \pm 29,1$ & $35,6 \pm 10,8$ & $\mathbf{0 . 0 5} / 0.64$ \\
\hline ALT (U/L) & $36,6 \pm 28,8$ & $34,4 \pm 14,5$ & $39,2 \pm 32,5$ & $34,9 \pm 10,6$ & $0.27 / 0.66$ \\
\hline $\mathrm{LDH}(\mathrm{U} / \mathrm{L})$ & $351,4 \pm 164,4$ & $157,8 \pm 106,2$ & $340,1 \pm 188,5$ & $212 \pm 85,1$ & $0.55 / \mathbf{0 . 0 2}$ \\
\hline GGT (U/L) & $37,1 \pm 28,4$ & $22,3 \pm 14,9$ & $39,3 \pm 23,2$ & $30,6 \pm 28,1$ & $0.44 / \mathbf{0 . 0 3}$ \\
\hline ALP (U/L) & $79,6 \pm 35,2$ & $67,2 \pm 30,4$ & $78,1 \pm 38,5$ & $69 \pm 25,2$ & $0.56 / 0.52$ \\
\hline Sodium (mmol/L) & $137,5 \pm 6,1$ & $145,2 \pm 2,8$ & $139,1 \pm 3,1$ & $142,6 \pm 2,4$ & $0.3 / 0.4$ \\
\hline Potassium (mmol/L) & $4,2 \pm 0,6$ & $4,5 \pm 0,7$ & $4,2 \pm 0,4$ & $4,4 \pm 0,5$ & $0.8 / 0.49$ \\
\hline Creatine (mg/dL) & $1,1 \pm 0,8$ & $1,1 \pm 0,7$ & $1,1 \pm 0,4$ & $1,2 \pm 0,8$ & $0.84 / 0.45$ \\
\hline Prothrombin time (s) & $18,3 \pm 10,4$ & $16,6 \pm 4,1$ & $17,8 \pm 7,1$ & $16,4 \pm 2,8$ & $0.09 / 0.33$ \\
\hline $\mathrm{CRP}(\mathrm{mg} / \mathrm{dL})$ & $38,7 \pm 15,8$ & $10,2 \pm 9,8$ & $37,5 \pm 16,8$ & $14,2 \pm 15,1$ & $0.37 / \mathbf{0 . 0 0 1}$ \\
\hline Troponin-I (ng/dL) & $16,1 \pm 10,3$ & $14 \pm 7,9$ & $17,9 \pm 15,3$ & $13,2 \pm 9,2$ & $0.61 / 0.24$ \\
\hline D-Dimer (ng/mL) & $995,9 \pm 810,7$ & $217,2 \pm 314,5$ & $966,6 \pm 855,2$ & $376,7 \pm 416,2$ & 0.54 / $\mathbf{0 . 0 1}$ \\
\hline Ferritin $(\mathrm{ng} / \mathrm{mL})$ & $794,5 \pm 379,2$ & $280,4 \pm 86,6$ & $796,7 \pm 294,1$ & $314.6 \pm 79.4$ & $0.23 / \mathbf{0 . 0 2}$ \\
\hline
\end{tabular}

MAS: Macrophage activation syndrome, WBC: White blood cells, NLR: Neutrophil/lymphocyte ratio, AST: Aspartate aminotransferase.

ALT: Alanine aminotransferase, LDH: Lactate dehydrogenase, GGT: Gamma glutamyl transferase, ALP: Alkaline phosphatase.

$\mathrm{P}$ : Comparison of parameters at time of admission and day 5 of treatment between groups. 
TABLE 2: COMPARISON OF SYMPTOMS AND QUANTITY OF PCR POSITIVE DAYS IN PATIENTS USING AND NON-USING VIRUTHOL

\begin{tabular}{cccc}
\hline & $\begin{array}{c}\text { Viruthol } \\
\text { group (n:75) }\end{array}$ & $\begin{array}{c}\text { Control group } \\
\text { (n:75) }\end{array}$ & $\mathrm{P}$ \\
\hline Fever (n / day) & $64 / 3,2 \pm 2,1$ & $69 / 7,4 \pm 3,8$ & $\mathbf{0 , 0 0 1}$ \\
$\begin{array}{c}\text { Headache (n / day) } \\
\text { Weakness (n / day) }\end{array}$ & $\begin{array}{c}52 / 2,4 \pm 2,2 \\
42 / 2,2 \pm 2,1\end{array}$ & $70 / 4,2 \pm 2,2$ & $\mathbf{0 , 0 5}$ \\
Loss of Taste and Smell \\
$\begin{array}{c}\text { (n / day) } \\
\text { Muscle- Joint Pain } \\
\text { (n / day) }\end{array}$ & $34 / 6,1 \pm 4,1$ & $33 / 9,1 \pm 5,9$ & $\mathbf{0 , 0 0 1}$ \\
$\begin{array}{c}\text { Nausea, Vomiting } \\
\text { Diarrhea } \\
\text { (n / day) }\end{array}$ & $65 / 2,8 \pm 2,7$ & $68 / 4,1 \pm 3,1$ & $\mathbf{0 , 0 0 1}$ \\
PCR positivity time (day) & $7,1 \pm 3,8$ & $9,1 \pm 5,2$ & 0,06 \\
\hline
\end{tabular}

p: Comparison of symptoms and quantity of PCR positive days in patients using and non using Viruthol.

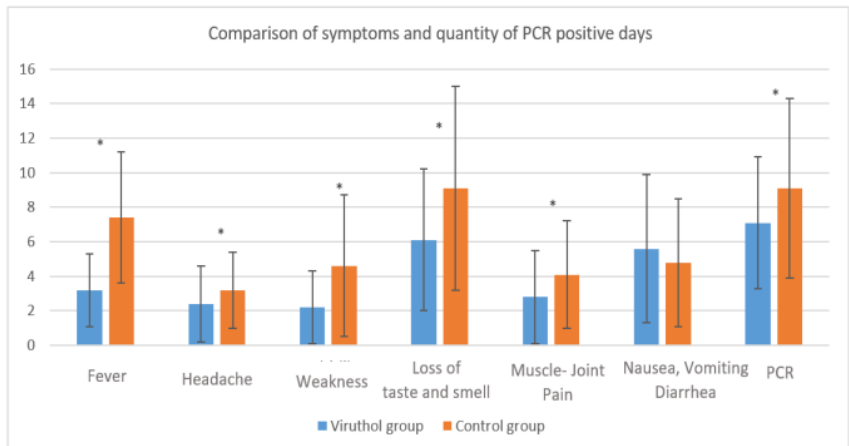

Fig. 1. Comparison of symptoms and quantity of PCR positive days in patients using and non-using Viruthol ${ }^{\circledR}$.

$\mathrm{p}^{*}$ : In the comparison of symptoms and quantity of PCR positive days $\mathrm{p}<0,05$.

\section{DISCUSSION}

In this study, we observed that administration of Viruthol ${ }^{\circledR}$ in addition to the standard treatment protocol resulted in a faster lowering of LDH, CRP, D-dimer and ferritin levels. On the other hand, lymphopenia caused by SARS-CoV-2 virus, which mainly affects T-lymphocytes, increased in Viruthol ${ }^{\circledR}$ group on the $5^{\text {th }}$ day with respect to control group. The COVID-19 symptoms recovered more rapidly, and PCR negativity time was also shorter than control group.

In December 2019, a new virus was identified in Wuhan/China which was further named as Severe Acute Respiratory Syndrome coronavirus-2 (SARS-CoV-2) by the International Virus taxonomy Committee and COVID-19 by the World Health Organization. SARS-CoV-2 is highly related to SARS-CoV and MERS-CoV that caused previous epidemic with high morbidity and mortality. COVID-19 is rapidly spreading globally and up to date more than 60 million people were effected [31].

Laboratory tests revealed that in most of the patient's lymphopenia was observed. It makes us conclude that SARS-CoV-2 is mainly effecting T-lymphocytes as it was done by SARS-CoV previously [32]. The virus spreads from respiratory mucous and infects other cells that results in cytokine storm in the body. It is thought that T-lymphocyte damage is mainly responsible for that situation [33]. Therefore, we think that lymphopenia may be used as a reference parameter for diagnosis of COVID-19. In addition to lymphopenia high levels of LDH, CRP, D-Dimer and ferritin may also be related to serious prognosis in patients [34].
The active ingredient of Viruthol ${ }^{\circledR} 2$-aticyto complex (purified flavonoid and polyphenol fractions); is a special compound that contains "the certain extent of flavonoid and polyphenol fractions that are produced by purification of Helichrysum sp., Hibiscus sabdariffa, Thymbra spicata L. and Rosa canina L. plants by nanotechnological methods" and also "sodium alginate which is a natural polysaccharide product obtained from the cell wall of brown seaweed grown in cold water regions".

2-aticyto complex provides the treatment of complaints caused by viruses, bacteria or parasites affecting the mucosal membrane with its purified flavonoid and polyphenol fractions. Meanwhile it prevents the adhesion of these agents on the superficial epithelial layers through the strong barrier which is created by sodium alginate on the mucous membrane.

The aim of this study was to compare the effect of 2 aticyto complex on SARS-CoV-2 infection with respect to other antiviral agents. In patients of Viruthol ${ }^{\circledR}$ group, COVID-19 symptoms recovered more rapidly and indicators of this disease such as LDH, CRP, D-Dimer and ferritin levels decreased significantly of the $5^{\text {th }}$ day showing that Viruthol ${ }^{\circledR}$ might be considered as an alternative treatment perspective for COVID-19 patients. The increment of the lowering in lymphocyte levels in Viruthol ${ }^{\circledR}$ group may be commented in the way that 2-aticyto complex improves the maturation of T-lymphocytes. We think that antiviral effect of flavonoids and polyphenols in 2-aticyto complex in addition to strong barrier effect of sodium alginate on mucosa membrane resulted in shorter PCR negativity time with respect to control group. The major limitation of this study was the supportive administration of Viruthol ${ }^{\circledR}$ in addition to the official treatment procedure. We were not able to administer Viruthol ${ }^{\circledR}$ alone, since it was legally prohibited to follow a treatment scheme except guideline recommended by the Ministry of Health. On the other hand, we believe that this study will be a pioneer for the future studies.

As well known, COVID-19 pandemic has become a global health problem with respect to very rapid spreading of the virus and even if more that approximately one year of time over the first days, there exists no molecule that has power to affect this virus. The side effects and limitations of the existing medical treatment options make alternative effective treatment options more crucial.

\section{CONCLUSIONS}

As a result of these facts, not only with the enhanced efficacy in this study, but also with the inexistence of any side effects, Viruthol ${ }^{\circledR}$ has been evaluated as a new effective agent that may be classified as an alternative therapy for SARS-CoV-2 infections.

\section{CONFLICT OF INTEREST STATEMENT}

The authors received no financial support for the research and/or authorship of this article. The authors declare that they have no conflict of interest to the publication of this article. 


\section{ETHICAL APPROVAL}

All procedures performed in studies involving human participants were in accordance with the ethical standards of the institutional and/or national research committee and with the 1964 Helsinki declaration and its later amendments or comparable ethical standards.

\section{INFORMED CONSENT}

Informed consent was obtained from all individual participants included in the study.

\section{CREDIT AUTHOR STATEMENT}

Conceptualization, Methodology, Software, Validation, Formal analysis B.K, F.K, Investigation, Resources, Data Curation B.K, A.A.., Writing - Original Draft, Writing Review \& Editing F.K, B.K, A.O.K, Visualization, Supervision, Project administration B.K, A.O.K.

\section{REFERENCES}

[1] Wiersinga WJ, Rhodes A, Cheng AC, Peacock SJ, Prescott HC. Pathophysiology, transmission, diagnosis, and treatment of coronavirus disease 2019 (COVID-19): a review. Jama. 2020;324(8):782-93.

[2] Carfî A, Bernabei R, Landi F. Persistent symptoms in patients after acute COVID-19. Jama. 2020;324(6):603-5.

[3] Group RC. Effect of hydroxychloroquine in hospitalized patients with Covid-19. New England Journal of Medicine. 2020.

[4] Chen C, Huang J, Cheng Z, Wu J, Chen S, Zhang Y, et al. Favipiravir versus arbidol for COVID-19: a randomized clinical trial. MedRxiv. 2020.

[5] Beigel JH, Tomashek KM, Dodd LE, Mehta AK, Zingman BS, Kalil $\mathrm{AC}$, et al. Remdesivir for the treatment of Covid-19-preliminary report. The New England journal of medicine. 2020.

[6] Benzie IF, Strain J. [2] Ferric reducing/antioxidant power assay: direct measure of total antioxidant activity of biological fluids and modified version for simultaneous measurement of total antioxidant power and ascorbic acid concentration. Methods in enzymology. 299: Elsevier; 1999. p. 15-27.

[7] Syed AA, Knowlson S, Sculthorpe R, Farthing D, DeWilde C, Farthing CA, et al. Phase I safety trial of intravenous ascorbic acid in patients with severe sepsis. Journal of translational medicine. 2014;12(1):32.

[8] Formica J, Regelson W. Review of the biology of quercetin and related bioflavonoids. Food and chemical toxicology. 1995;33(12):1061-80.

[9] Robaszkiewicz A, Balcerczyk A, Bartosz G. Antioxidative and prooxidative effects of quercetin on A549 cells. Cell biology international. 2007;31(10):1245-50.

[10] Uchide N, Toyoda H. Antioxidant therapy as a potential approach to severe influenza-associated complications. Molecules. 2011;16(3):2032-52.

[11] Nair MP, Kandaswami C, Mahajan S, Chadha KC, Chawda R, Nair $\mathrm{H}$, et al. The flavonoid, quercetin, differentially regulates Th-1 (IFN $\gamma$ ) and Th-2 (IL4) cytokine gene expression by normal peripheral blood mononuclear cells. Biochimica et Biophysica Acta (BBA)-Molecular Cell Research. 2002;1593(1):29-36.

[12] Shinozuka K, Kikuchi Y, Nishino C, Mori A, Tawata S. Inhibitory effect of flavonoids on DNA-dependent DNA and RNA polymerases. Experientia. 1988;44(10):882-5.

[13] Labarrere CA, Woods J, Hardin J, Campana G, Ortiz M, Jaeger B, et al. Early prediction of cardiac allograft vasculopathy and heart transplant failure. American Journal of Transplantation. 2011;11(3):528-35.

[14] Spedding G, Ratty A, Middleton Jr E. Inhibition of reverse transcriptases by flavonoids. Antiviral research. 1989;12(2):99-110.

[15] Chusnie T, Lamb A. Antimicrobial activity of flavonoid. Int J Antimicrob Agent. 2005;26:343-56.

[16] Pagani L. Effects of propolis flavonoids on virus infectivity and replication. Microbiologica. 1990;13:207-13.
[17] Pilau MR, Alves SH, Weiblen R, Arenhart S, Cueto AP, Lovato LT Antiviral activity of the Lippia graveolens (Mexican oregano) essential oil and its main compound carvacrol against human and animal viruses. Brazilian Journal of Microbiology. 2011;42(4):1616 24.

[18] Mollova S, Fidan H, Antonova D, Bozhilov D, Stanev S, Kostova I, et al. Chemical composition and antimicrobial and antioxidant activity of Helichrysum italicum (Roth) G. Don subspecies essential oils. Turkish Journal of Agriculture and Forestry. 2020:44.

[19] Czinner E, Lemberkovics É, Bihátsi-Karsai E, Vitányi G, Lelik L. Composition of the essential oil from the inflorescence of Helichrysum arenarium (L.) Moench. Journal of Essential Oil Research. 2000;12(6):728-30.

[20] Do THA, Le HH, Kitsamone S, Nguyen TU, Nguyen QH. In vitro Antibacterial Activity of Quercetin Containing Extract from Hibiscus Sabdariffa L. Calyxes. 2016.

[21] Daneshvar-Royandezagh S, Khawar K, Ozcan S. In Vitro micropropagation of garden thyme (Thymbra Spicata L. Var. Spicata L.) collected from southeastern turkey using cotyledon node Biotechnology \& Biotechnological Equipment. 2009;23(3):1319-21.

[22] Duran N, Kaya A, Gulbol Duran G, Eryilmaz N. In vitro antiviral effect of the essential oils of Thymbra spicata L. on Herpes simplex virus type 2. ICAMS; 2012.

[23] Demir F, Özcan M. Chemical and technological properties of rose (Rosa canina L.) fruits grown wild in Turkey. Journal of food engineering. 2001;47(4):333-6.

[24] Ercişli S, Eşitken A. Fruit characteristics of native rose hip (Rosa spp.) selections from the Erzurum province of Turkey. New Zealand Journal of Crop and Horticultural Science. 2004;32(1):51-3.

[25] Ziegler S, Meier B, Sticher O. Fast and selective assay of L-Ascorbic Acid in rose hips by RP-HPLC coupled with electrochemical and/or spectrophotometric detection. Planta medica. 1986;52(05):383-7.

[26] Kilıçü̈n H, Altıner D. Correlation between antioxidant effect mechanisms and polyphenol content of Rosa canina. Pharmacognosy magazine. 2010;6(23):238.

[27] Egea I, Sanchez-Bel P, Romajaro F, Pretel M. Replace synthetic additives in functional foods as a natural antioxidant. Plants Foods Hum Nutr. 2010;65:121-9.

[28] Gökbulut İ, Öztürk FS. Gıda mikrokapsülasyonunda aljinat kullanımı. Batman Üniversitesi Yaşam Bilimleri Dergisi. 2018;8(1/2):16-28.

[29] Lee KY, Mooney DJ. Alginate: properties and biomedical applications. Progress in polymer science. 2012;37(1):106-26.

[30] Sosnik A. Alginate particles as platform for drug delivery by the oral route: state-of-the-art. International Scholarly Research Notices. $2014 ; 2014$.

[31] Sanders JM, Monogue ML, Jodlowski TZ, Cutrell JB. Pharmacologic treatments for coronavirus disease 2019 (COVID-19): a review. Jama. 2020;323(18):1824-36.

[32] Wang F, Nie J, Wang H, Zhao Q, Xiong Y, Deng L, et al. Characteristics of peripheral lymphocyte subset alteration in COVID19 pneumonia. The Journal of infectious diseases. 2020;221(11):1762-9.

[33] Vaninov N. In the eye of the COVID-19 cytokine storm. Nature Reviews Immunology. 2020;20(5):277.

[34] Ali A, Mohamed S, Elkhidir I, Elbathani M, Ibrahim A, Elhassan A, et al. The Association of Lymphocyte count and levels of CRP, DDimer, and LDH with severe coronavirus disease 2019 (COVID-19): A Meta-Analysis. medRxiv. 2020. 